\section{The Thunderstorms of May 29 and the Louth Disaster.}

THE last week of May was marked by hot weather all over the country and by numerous thunderstorms, which culminated in the notable downpours of rain which occurred on Saturday, May 29. The highest temperatures were reported on Tuesday, May 25, when $82^{\circ} \mathrm{F}$. was reached in London and the Thames Valley. In London the magnificent cumulus clouds made a fine spectacle, but it was further north, in the neighbournood of Luton, that thunderstorms occurred. Paris suffered from a severe storm on the same day.

On Wednesday, May 26, when an area of comparatively low pressure extended across England and Ireland, there were thunderstorms in London and in other parts of the country during the afternoon. The rainfall in the west of London was exceptionally heavy. The area affected was somewhat sharply outlined on the west. At Hammersmith the roads were flooded and wood pavements burst up by the water, but at the Meteorological Office, a couple of miles away, only $2 \mathrm{~mm}$. of rain fell. At Uxbridge $33 \mathrm{~mm}$. fell in half an hour.

The distribution of pressure remained irregular, but lower over the British Isles than over neighbouring countries, and on Friday evening a "low," which appears to have originated over the South of France, began to deepen and to move northward. The map for 7 h. G.M.T. on Saturday, May 29, indicates the depression by the isobar 1012.5 mb. over the Bristol Channel. At 13 h. pressure was below rol $2 \mathrm{mb}$. over the Midlands. By $\mathrm{I} 8 \mathrm{~h}$. it had fallen to $1009 \mathrm{mb}$. in the same region. On Sunday morning the depression was over the North Sea, and by the evening, when it had deepened to $1004 \mathrm{mb}$., it was centred at the Shetlands.

The rainfall on May 29 was insignificant in the South of England, but falls of half an inch or more were general from Nottingham northwards. The exceptional falls in Lincolnshire and Lancashire occurred before the northward passage of the trough of lowest pressure. As to the downpour in Lincolnshire, to which the damage and loss of life at Louth are to be attributed, records are available from $\mathrm{Hal}-$ lington, in the valley west-south-west of the town, and from Elkington $\mathrm{Hall}$, on the hills to the northwest. In each case the measurement was about I20 $\mathrm{mm}$. in two hours, giving a mean rate of fall of I mm. per minute. According to newspaper reports, Ioo $\mathrm{mm}$. fell at Horncastle, twelve miles south-southwest of Louth.

The area with an exceptionally heavy rainfall included Bucknall, sixteen miles south-west of Louth, with a total fall of $54 \mathrm{~mm}$; at Lincoln, twenty-four miles away, the fall was $52 \mathrm{~mm}$.; and at Spurn Head, to the north, it was $35 \mathrm{~mm}$. The boundary of the area of heavy rain is marked by $34 \mathrm{~mm}$. at Cranwell and $12 \mathrm{~mm}$. at Fulbeck. these places being about four miles apart on either side of the Ermine Street, south of Lincoln. At Skegness only $\mathrm{I} 2 \mathrm{~mm}$. fell. There were two thunderstorms in the afternoon, both carried westward by the wind on the north side of the cvclone. One was at Skegness at I3.I5 G.M.T., and at Lincoln at 14.30. The other, which was the more severe. moved more slowlv, passing Skegness at I6h. and Lincoln between 18.30 and $\mathrm{roh}$.

The Louth disaster seems to have been associated with the former storm. From the evidence at the inquest of a witness from Benniworth, a village on the far side of the Wolds, in the Bain Valley, it appears that after a little rain between $12 h$. and i4. I5 the weather cleared. but that at 14.30 the rain suddenly poured so fast that the house-pipe could not NO. $264 \mathrm{I}$, VOL. IO5] carry it. "In a moment the fields were at least 8 in. deep in water. I saw a huge cloud in the shape of an egg which kept twisting round. There were three flashes of lightning, very vivid and very shocking. One seemed to pierce through the cloud, and immediately afterwards the cloud seemed to come earthward.",

Examination of the ground by the deputy coroner indicated that the heavier rainfall had been on the north side of the line from Louth to Lincoln, and that it was more severe higher up the valley than at Hallington, where the rain-gauge, which measured I $20 \mathrm{~mm}$., was situated. It is likely that the $120 \mathrm{~mm}$. is a fair average for the fall over the basin of the Lud above Louth. This basin contains three or four brooks which unite above the town and drain an area of about 20,000 acres. The Wolds are chalk hills, however, and no doubt the greater part of the normal drainage is underground. This may account for the absence of any provision for the passage of floodwater, but much of the ground slopes at about Ioo ft. to the mile, so that water would run off rapidly. Rainfall at the rate of I mm. per minute over an area of $80 \mathrm{sq}$. $\mathrm{km}$. would feed a stream 5 metres deep and roo metres wide rushing along at I6o metres a minute, and the Lud does not appear to have reached such a magnitude as this. The town seems to have been singularlv fortunate in escaping floods in the past, as a rainfall of even one-quarter of that on the present occasion could scarcely have found its way through the narrow bridges of the town.

With regard to the heavy falls in Lancashire, we are so fortunate as to have the autographic record from the rain-gauge at Leyland, to the south of Preston. The total fall for the twenty-four hours, 9h.-oh. May 30-?I, is about $80 \mathrm{~mm}$., "the like of which the proverbial oldest inhabitant cannot remem. ber." The heaviest downpours were from 16.30 to I7h. and from 17.55 to I8.I5. In the latter interval of twenty minutes no less than $40 \mathrm{~mm}$. were recorded. The more dramatic exploits of the flood-water due to this storm appear to have been to the north of Preston, where the main line of the London and North-Western Railway was interrupted by the destruction of the embankment near the crossing of the River Brock. In soite of the long duration of the rain at Preston. the fall at Blackpool, fifteen miles to the west, amounted to only $5 \mathrm{~mm}$. in the twenty-four hours.

\section{Annual Meeting of the British Science Guild.}

THE annual meeting of the British Science Guild was held in the Goldsmiths' Hall on Tuesday, June 8 , the chair being taken by Lord Sydenham, president of the guild.

In his address on "Science and the Nation" the president referred to the strike evil as one of the great industrial problems of the day. 'The moulders' strike had seriously affected many industries; loss in coal had reached $50,000,000$ tons a year as compared with I913, with serious consequences to the export trade. The evil was due partly to an abnormal state of mind arising from the war, but was originally fostered by the industrial changes of the last century, namely, the general use of machinery, rendering labour monotonous and leaving less room for the individual skill of the craftsman, and the formation of large companies, whereby the personal touch between master and man was lost. Capital unduly concentrated in a few hands might lead to tvranny. This country needed a wider distribution of capital. Labour and capital must be reconciled, and science must find an 